\title{
Barcın Höyük, a seventh millennium settlement in the Eastern Marmara region of Turkey
}

\author{
Fokke Gerritsen ${ }^{1}$, Rana Özbal ${ }^{2}$ \\ 1 Netherlands Institute in Turkey, Istanbul, TR \\ fa.gerritsen@nit-istanbul.org \\ 2 Koç University, Istanbul, TR \\ rozbal@ku.edu.tr
}

\begin{abstract}
Recent excavations at the site of Barcin Höyük provide a detailed view of a settlement founded and inhabited during the early stages of the Neolithic of the Marmara Region of northwestern Anatolia. The occupation history of the site complements and extends further back in time the regional sequence as it had been established for the eastern Marmara Region on the basis of excavations at nearby Menteșe, Aktopraklk and Ilpinar, and Fikirtepe and Pendik in the Istanbul environs. The site of Barcin Höyük is therefore of critical importance for our understanding of the initial neolithisation of northwestern Anatolia. This paper summarizes some of the main findings of the Barcin Höyük excavations with regard to the Neolithic occupation phases.
\end{abstract}

KEY WORDS - neolithisation; spread of farming; Northwestern Anatolia; settlement; migration

\section{Barcın Höyük, naselbina iz 7. tisočletja $v$ regiji Vzhodna Marmara $v$ Turčiji}

\begin{abstract}
IZVLEČEK - Na podlagi nedavnih izkopavanj na najdišču Barcin Höyük dobimo bolj natančen vpogled $v$ naselbino, ki je bila osnovana in poseljena v času zgodnjega obdobja neolitika v regiji Marmara na območju severozahodne Anatolije. Poselitvena zgodovina tega najdišča tako dopolnjuje regionalno sekvenco, ki je bila postavljena za območje Vzhodne Marmare na podlagi izkopavanj na bližnjih najdiščih Mentessse, Aktoprakllk in Ilppnar ter na najdiščih Fikirtepe in Pendik blizu Istanbula, ter jo celo postavlja v zgodnejše obdobje kot doslej domnevano. Najdišč Barcın Höyük je tako izredno pomembno za razumevanje začetne neolitizacije severozahodne Anatolije. Včlanku povzemamo podatke o glavnih odkritjih pri izkopavanjih na najdišč glede na poselitvene faze, vezane na obdobje neolitika.
\end{abstract}

KLJUČNE BESEDE - neolitizacija; prehod na kmetovanje; severozahodna Anatolija; naselbina; preseljevanje

\section{Introduction}

Research on the pre-Bronze Age cultures of the Marmara Region began relatively early in the history of Anatolian archaeology, and has seen concerted efforts over the last few decades to document through a number of excavations the early cultural history of the region and to build provisional neolithisation models for this region at the transition between Anatolia and Europa (Fig. 1). The excavations at Bar- cın Höyük have been conducted as part of this effort. Barcın Höyük was first recognized as a prehistoric site and recorded as Yenişehir II in surveys by James Mellaart and David French (Mellaart 1955; French 1967). Following long-term excavations during the 1980s and 1990s at the 6th millennium site of Ilipinar (Roodenberg 1995; Roodenberg, Thissen 2001; Roodenberg, Alpaslan Roodenberg 2008) and 
soundings at the 7 th millennium site of Mentesse ( $R O$ odenberg 1999), Jacob Roodenberg initiated excavations at Barcın Höyük in 2005. In 2007 the authors of this article took over responsibility and conducted nine consecutive excavation campaigns until 2015. The project has taken place under the auspices of the Netherlands Institute in Turkey, in close partnerships with colleagues at Turkish universities, in particular at Koç University, Boğaziçi University and Ege University, and in collaboration with an international team of specialist researchers. At present, the project team is preparing specialist studies and final publications.

\section{Environmental setting}

The site of Barcin Höyük is currently located among arable fields in the centre of the Yenişehir Plain. Well into the $20^{\text {th }}$ century $\mathrm{AD}$, the valley bottom was prone to seasonal flooding. A small lake a few kilometres to the west of the site existed until 1950, when a drainage canal was dug to drain the lake water and the surrounding swamps (Aksoy, Özügül 2014). Palynologists Bottema and Woldring of Groningen University cored the dried lakebed for pollen and published a vegetation sequence covering much of the early Holocene period (Bottema, Woldring 1995; Bottema et al. 2001).

A small program of coring on and around the mound was carried out to reconstruct the local environmental conditions during the Neolithic. Geoarcheologists Sjoerd Kluiving, Mark Groenhuijzen and Michiel Künzel of Vrije Universiteit Amsterdam established that the first settlers selected a slight natural elevation of coarse sand at the northern edge of a lake or marsh (Groenhuijzen et al. 2015). Nearby access to a wetland environment to the south of the settlement, as well as drier terrain to the north, may have been a consideration in the selection of the site location. During the centuries of Neolithic occupation, the edge of this lake or marsh appears to have withdrawn further away from the edge of the mound. Subsequent millennia indicate fluctuations in the distance of the site to nearby standing or flowing water. As the outcome of a complex history of deposi- tion and removal of sediment, the current level of the plain $100 \mathrm{~m}$ away from the edge of the mound at $c .225 .20 \mathrm{~m}$ lies $1.2 \mathrm{~m}$ higher than the base of the mound at $224.00 \mathrm{~m}$.

\section{General occupation history}

The current archaeological site consists of two low mounds connected by a saddle covering an area of about 1.7 ha. The smaller, western mound was not excavated. Surface collections indicate that occupation there postdates the Bronze Age. On the eastern mound, excavations concentrated on a transect running from the centre down the southern slope of the mound. Contiguous areas between 250 and $550 \mathrm{~m}^{2}$ were exposed of each of the Neolithic occupation phases. The excavations established that, following the abandonment of the Neolithic settlement, parts of the site were intermittently reoccupied. This includes brief occupation episodes during the Middle Chalcolithic Period, the Late Chalcolithic Period (Gerritsen et al. 2010; Özbal et al. 2017), the Early Bronze Age, and the Early to Middle Bronze transition. Mound formation during these periods was limited. A last phase of use of the site occurred during the Byzantine Period, when the eastern mound was used as a burial ground (Alpaslan Roodenberg 2009; Roodenberg 2009).

\section{Neolithic architecture and settlement layout}

The Neolithic settlement existed continuously for approximately six centuries. Based on a combination of stratigraphic observations, building horizons, ce-

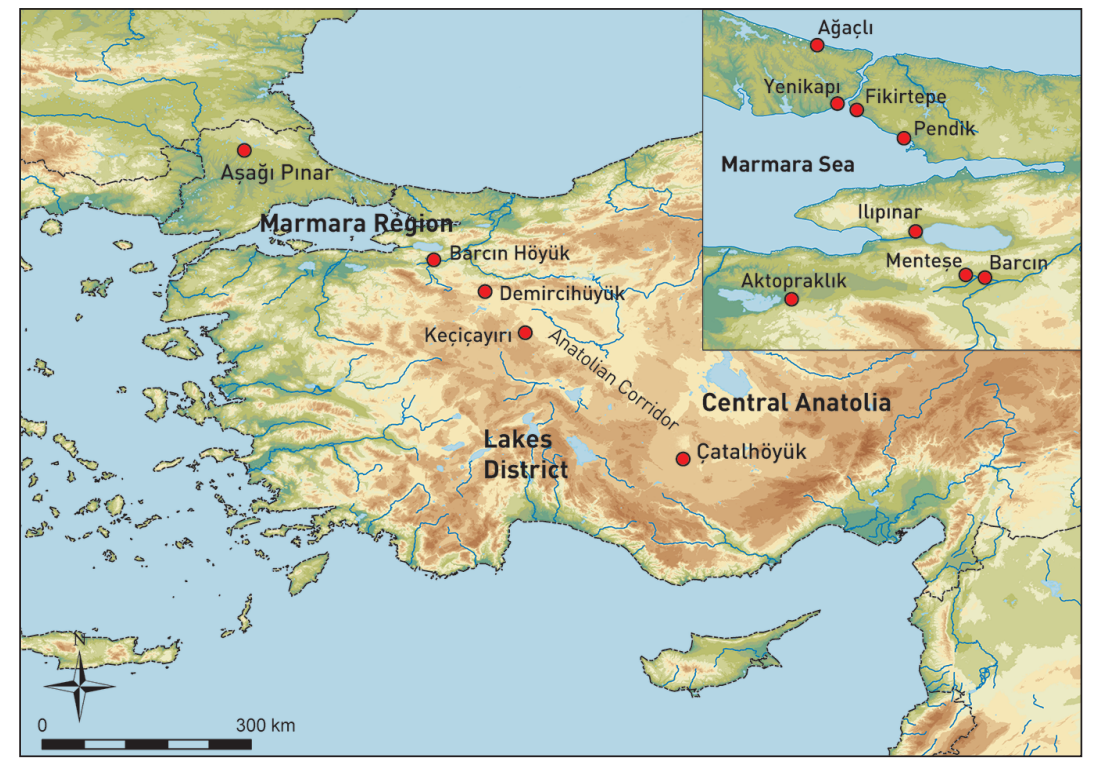

Fig. 1. Map of central and western Anatolia with the location of regions and sites mentioned in the text. 
ramic developments and ${ }^{14} \mathrm{C}$ dates, this period has been subdivided into seven phases, labelled from old to young: VIe, VId1, VId2, VId3, VIc, VIb and VIa.

The architecture shows a significant degree of continuity throughout much of the occupation period, with rectangular buildings made of wood and loam. The structural timber is placed in foundation ditches for the walls and in postholes for roof bearing posts. Loam is used to fill the spaces between and around rows of wall posts in order to create closed walls. Evidence of wattling is strikingly absent, even in cases where buildings burnt down and yielded ample impressions of building wood in the burnt loam debris. Entrances are located in the long sides of the buildings. The architecture of the oldest building phase (VIe) appears to differ somewhat from the later phases, making use of heavy posts set in individual postholes rather than in foundation ditches.

In terms of settlement layout, however, the general pattern established in phase VIe was adhered to throughout the following phases until an apparent reorganization of settlement space in VIb. During the early phases, VIe and VId 1 (c. 6600-6400 cal BC), there was a row of buildings oriented EastWest, facing a large open space, that dipped into a natural depression, probably with further architecture beyond the depression to the south (Fig. 2). In the course of the early phases, the depression became filled up with midden deposits.

During the middle phases, VId2, VId 3 and VIc (c. 6400-6200 cal BC), houses continued to be erected in the same central East-West strip, and the open space to the south continued to be used for outdoor activities, including fire pits and other installations. The courtyard was also frequently used to bury adult individuals in flexed position in simple pit graves (Alpaslan Roodenberg et al. 2013). Infants tended to be buried inside or in the direct vicinity of the houses. During the middle phases, the southern part of the courtyard became built up. The architectural remains and installations in this area are less well preserved than in the central part, but appear to have been of the same rectangular type, with postrows set in foundation ditches as elsewhere in the settlement. Similarly, there is evidence for one or multiple buildings appearing to the north of the central buildings, separated by an open space. Judging by the limited exca- vated area, therefore, it appears that the number of buildings in the settlement expanded during the middle phases of occupation, possibly connected to an increase in the population.

With the transition from VIc to VIb, around $6200 \mathrm{cal}$ $\mathrm{BC}$, new buildings appear in two of the areas that had functioned as open courtyard areas during all previous centuries of occupation. Assuming that the former courtyards had been communally used until then, this suggests a reorganization of settlement space connected to new property practices. The architecture of VIb again consists of post-row buildings, but these now stand individually rather than agglomerated, as before (Gerritsen et al. 2013a.Fig. 6). They appear to have had small annexes or side rooms attached to them. Architectural remains of phase VIa are very fragmentary, and it is impossible to say to what extent the spatial layout continues the pattern established in phase VIb.

\section{Subsistence economy}

Studies of the subsistence economy are ongoing, but preliminary results of palaeobotanical and archaeo-

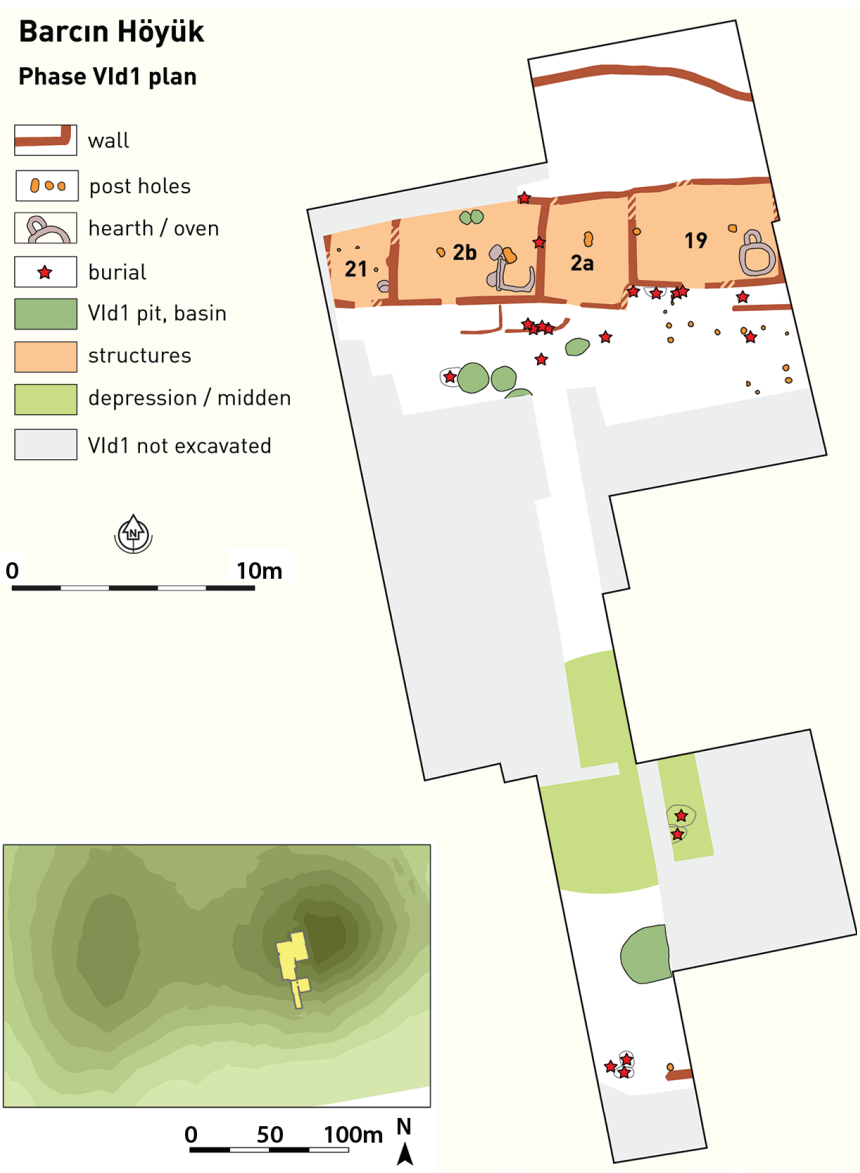

Fig. 2. Barcin Höyük; generalized overview of the excavated remains of phase VId1 (6500-6400 cal BC). 
zoological analyses indicate that its main components were agriculture and animal husbandry. There appear to have been minor changes in the relative importance of specific crops and animals, but it is clear that the first settlers were farmers and that this remained the case throughout the habitation history of the settlement.

The botanical samples analysed to date number over 450 (1318 liters of soil), with an overrepresentation of samples from the early phases VIe and VId1 (Cappers, Balci n.d.; Balci et al. 2019). The samples represent a broad array of settlement contexts: indoor and outdoor surfaces and deposits, ovens, hearths and storage features, as well as pits and midden fills. With the exception of a single store of charred lentils from Structure $2 \mathrm{a}$ in phase VId1, crops stores were not encountered. This suggests that viewed together, the samples give a representative picture of plants that were brought to the settlement and were processed and consumed there. Cultivated plant species included a wide range of cereals (Einkorn, Emmer, $\mathrm{Bread} / \mathrm{Hard}$ Wheat, hulled and naked barley) and pulses (lentil, pea, and chickpea), bitter vetch and flax. Additionally, hazelnut and blackberry count among the economic plants exploited at Barcin Höyük.

The animal economy relied largely on domesticated cattle, sheep and goat, with the first two being more frequent than the third (Galik 2013; Würtenberger 2012). With slight variations between the phases of the occupation history, wild animals are always a minor component of about 15\%. They include fallow and roe deer, wild boar, hare, fox, birds, terrapins, small rodents, fish and molluscs. Domesticated pig is absent in the Neolithic faunal assemblages from Barcin Höyük, supporting an emerging picture of the adoption of pig husbandry in the Marmara Region not before the Early Chalcolithic period (Arbuckle et al. 2014.Fig. 1).

\section{Pottery}

The ceramic assemblages of Neolithic Barcın Höyük provide a rich source to study the development of a ceramic tradition in the Eastern Marmara Region. This material has been and continues to be studied by Laurens Thissen (Thissen et al. 2010; Gerritsen et al. 2013b; De Groot et al. 2018).

In Phase VIe, pottery was made and used in small quantities. The central area of the settlement with structures 24 and 25 yielded only a handful of sherds.
The midden deposits in the depression excavated in L13 and M13 produced slightly larger numbers, mostly deriving from the upper deposits of VIe. Among these same VIe midden deposits, fire cracked stones occur in large quantities, whereas they are quite rare in levels following phase VIe. This has been interpreted as an indication that the earliest settlers relied mostly on hot-rock cooking techniques, and that subsequent generations abandoned this in favour of using cooking pots (Gerritsen et al. 2013a. 58; 2013b. 72-73).

The low intensity of ceramic production during phase VIe notwithstanding, the earliest settlers were accomplished potters. They made holemouth pots and bowls in schist tempered wares with burnished surfaces in light buff and greyish colours. During phase VId1, vessels walls become harder and thinner, while the repertoire of forms remains restricted. There is a switch to crushed calcite as the main tempering agent. Greatly increased quantities of sherds compared to VIe indicate a significant increase in the level of production in VId1. During subsequent phases VId 2 and VId3, the range of shapes increases, with bowls and pots with light S-profiles. Surfaces tend to have pastel colours in phase VId 2 and darker colours in VId3, highly burnished as before.

Ceramic traditions continue to develop during the later phases of occupation (VIc, VIb and VIa). New forms such as pots with four vertically pierced lugs or two lug handles and four-legged Fikirtepe boxes become common. There is now a greater variety in tempering additives, including quartz and sand. Dark, burnished surfaces are sometimes decorated with simple incised geometric patterns.

Overall, the ceramic assemblages of Barcın Höyük convey the development of gradual change within a consistent tradition (see Thissen in Gerritsen et al. 2013a; 2013b). Changes are introduced by building on and transforming existing practices of production rather than by radical changes. Comparisons with the ceramic assemblages of other $7^{\text {th }}$ millennium sites in the eastern Marmara Region are difficult to make with any precision because of the still limited extent of publication of ceramics from stratigraphic sequences. Nevertheless, it is clear that much of the ceramic sequence at Barcın Höyük predates what is termed Archaic and Classical Fikirtepe (Özdoğan 1999; 2019.Fig. 3). Barcin Höyük phases VIb and VIa, with their globular pots with pierced lugs and handles and Fikirtepe boxes show the best resemblances to the Fikirtepe traditions. This suggests 
that the Barcın Höyük ceramic sequence can be taken to represent the precursors and early stages of the Late Neolithic and Early Chalcolithic Fikirtepe tradition (Fig. 3). Beyond the eastern Marmara Region, parallels for the earliest Barcın Höyük ceramics (especially VIe) can be found at Demircihüyük (Seeher 1987) and Keçiçayırı (Akyol 2018) in nearby inland northwestern Anatolia.

\section{Lipid residue analyses}

An extensive program of lipid residue analysis on the ceramics from Barcin Höyük has been carried out under the direction of Hadi Özbal of Boğaziçi University, Istanbul. Preliminary reports have appeared (Thissen et al. 2010; Özbal H. et al. 2012; 2014 ) and a final publication of the results is in preparation. From over 1000 sampled sherds, lipid residues were successfully extracted and identified from 174. These represent all phases of the Neolithic occupation history and include small numbers of sherds from the brief Middle and Late Chalcolithic re-occupation phases of the site.

The analyses demonstrate that using ceramic vessels for milk processing occurred from phase VIe onwards. With minor variations between phases, the percentage of sherds with residues of milk fats is around or above $50 \%$. These findings substantiate the suggestion made by Evershed and his team that dairying became an important element of subsistence strategies in the Marmara Region, earlier and more dominantly than in other regions of Anatolia and southeastern Europe (Evershed et al. 2008). The lipid residue data from Barcın Höyük corroborate the faunal data. Aside from the milk lipids the data yielded numerous samples with ruminant adipose fats. Only small amounts of non-ruminant fats were discovered.

\section{Lithic technologies}

A large assemblage of some 17000 pieces of flint and obsidian has been studied and is currently being prepared for publication by Ivan Gatsov and Petranka Nedelcheva (preliminary studies in Gatsov, Nedelcheva 2009; 2016; in print; Gatsov et al. 2012).

Among the Barcin Höyük raw material, flint is much more common than obsidian, but during some of the occupation phases obsidian represents as much as a quarter of the assemblage. A preliminary study using pXRF points to Central Anatolia as the dominant source area for obsidian, possibly supplemented by materials acquired from Melos (Milić 2014) and unidentified sources (perhaps Galatian: Bigazzi et al. 1995; 1998.80-80).

Based on the research conducted by Gatsov and Nedelcheva, it is clear that lithic production at Barcin Höyük connects very well with the traditions that characterize the assemblages from sites of the Fikirtepe horizon, both typologically and technologically (Gatsov 2003; Gatsov, Nedelcheva 2009; 2016; Gatsov et al. 2012). Unidirectional blade cores, including bullet cores, are characteristic elements of the assemblage, as well as the blades and bladelets struck from them. Semi-circular and circular end-scrapers as well as high and macro end-scrapers are common among the tools. Sickle blades, blade perforators and drills, as well as a small number of trapezes also occur. There is evidence for pressure blade production, indirect percussion and direct percussion.

\section{Small finds}

The excavations at Barcin Höyük have yielded a large assemblage of finely made bone tools. Particularly striking are the spoons, which differ from spatulas in their pronounced distinction between the handle and spoon bowl (Erdalkiran 2016). Beads are made of stone and shell (Baysal 2014). Whereas in the earlier levels, dentalium shell beads dominate the assemblage, in the later levels turquoise coloured beads, probably made of bone, become common (Bursalı et al. 2017). Baked and unbaked clay human figurines occur in small numbers, from different levels of occupation (Gerritsen et al. 2013a; Özbal, Gerritsen 2019.Fig. 9).

In general, all categories of small finds, including also the ground stone tools and axes, display a development from a limited range of types, shapes and raw materials during the pioneer phases of VIe and VId1, to a much wider variety during the middle and late levels.

\section{Human DNA studies}

A total of 130 Neolithic graves were excavated at Barcın Höyük. A selection of the human skeletal remains from Barcin Höyük has been used for a series of genetic studies that focused on the grand narrative question of the nature of the expansion of farming from Anatolia and the Near East to Europe (Mathieson et al. 2015; Hofmanová et al. 2016; Lazaridis et al. 2016). Conducted at a time when full genomic analyses from Anatolia and the Near East were 
only just beginning to produce results, the skeletal remains from Barcın Höyük have been instrumental in establishing an 'Anatolian Farmer' genetic profile. Comparisons with genetic profiles of European hunter-gatherers and European Neolithic farmers from Hungary, Germany and the Iberian Peninsula showed that early European farmers derived almost all of their genetic ancestry from Anatolian farmers. This has now provided a strong case for migration-based theories of the expansion of farming to Europe.

Additional studies have used the genetic data from Barcin Höyük to track the genetic histories within Anatolia and the Near East. On present evidence, it appears that people at Barcın Höyük were genetically closely related to $9^{\text {th }}$ and $8^{\text {th }}$ millennium groups in Central Anatolia (Boncuklu), but also that as a group they were genetically more diverse than Central Anatolian groups, perhaps incorporating a modest genetic influx from populations from or genetically similar to the Levant (Kllınç et al. 2016; 2017). In the coming years new data will undoubtedly expand and refine this emerging picture of complex genetic histories.

\section{Regional and inter-regional setting}

The full-fledged farming economy of the earliest inhabitants of Barcin Höyük is the strongest indication that the settlers were newcomers to the region. Any acculturation processes of an indigenous population would be observable in the faunal and botanical assemblages, as well as in different artefact categories and architectural remains, but indications of this are absent. Given the ${ }^{14} \mathrm{C}$ dates that place the foundation of Barcin Höyük at around $6600 \mathrm{cal}$ $\mathrm{BC}$, it is clear that the site stands at the start of Neolithic presence in the region (Fig. 3), and therefore that the settlers at Barcın Höyük must have moved here as immigrants from outside the eastern Marmara Region (Özbal, Gerritsen 2019). Mainly on the basis of parallel developments in ceramic traditions, the Anatolian Corridor can be identified as the most likely route along which this population entered the region, with ancestral roots probably in western Central Anatolia and Çatalhöyük, and with intermediate sites such as Keçiçayırı and Demircihüyük as nodes in the network of the earliest pioneers that settled in the Marmara Region (Fig. 1). Whether there existed early contacts with the Lakes District, as sug- gested by Mehmet Özdoğan (2019.320), is more difficult to establish.

For the Fikirtepe Horizon, and specifically for the sites in the Istanbul environs, an indigenous component in the population has been suggested (Karul 2017.8; Özdogan 1999.210; 2019.320). This idea is based on a combination of evidence for Epipalaeolithic or Mesolithic hunter-gatherer groups in the region (the Ağaçlı group) and elements in the food economy and architecture at Neolithic sites like Fikirtepe and Pendik that do not seem to have their origins in a Neolithic way of life (Özdoğan 1999. 215). Different aspects of the idea of the Fikirtepe Horizon as a merging of indigenous and Neolithic traditions are being re-evaluated by various authors in light of new data (Cakırlar 2013; Özbal, Gerritsen 2019). Regardless of the nature of this cultural interaction elsewhere in the eastern Marmara Region, it is clear that hunter-gatherer influence in the Barcin Höyük community was very minimal at most, and probably completely absent.

In the course of the second half of the $7^{\text {th }}$ millennium, there appears to have been an increase in the number of settlements in the eastern Marmara Region, possibly as a result of a continuing influx of people from inland Anatolia as well as from indigenous population growth over the course of several centuries. The shared material culture traditions of

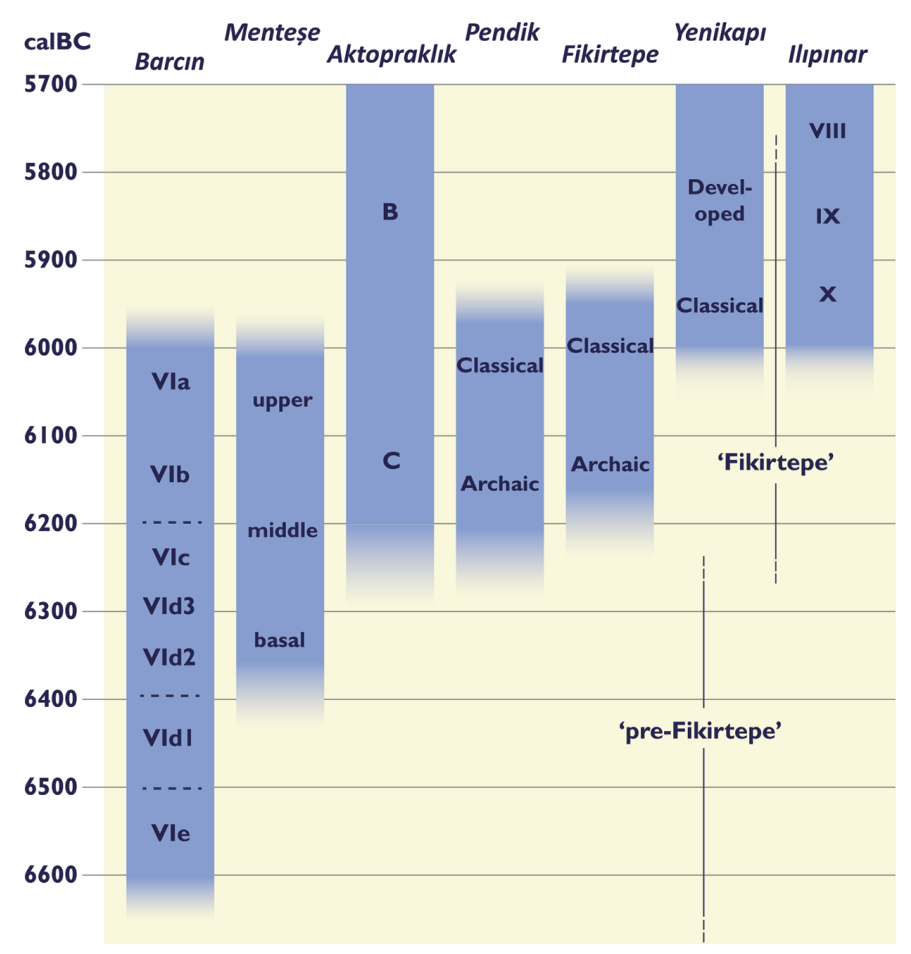

Fig. 3. Comparative periodization table of excavated sites in the eastern Marmara Region. 
these settlements inhabited during the final centuries before $6000 \mathrm{cal} \mathrm{BC}$ and into the beginning of the $6^{\text {th }}$ millennium cal $\mathrm{BC}$ have given rise to the term Fikirtepe Horizon or Fikirtepe Culture (Özdoğan 1979; 1983; 2013; Karul 2019). Although there remain site-specific differences and intra-regional distinctions, the later levels of Barcın Höyük, VIb and VIa, share this regional identity with other sites in the eastern Marmara Region. The long stratigraphic sequence of Barcin Höyük shows, moreover, that the genesis of the Fikirtepe Culture took place gradually over the course of several centuries.

In sharp contrast to the growing body of evidence for cultural interaction and interconnected developments within the eastern Marmara Region and with inland central-western Anatolia, we find many differences in material culture with eastern Thrace and the western Marmara Region (Özdoğan 2019). There appears to have been a distinct and lasting cultural boundary to the west of Istanbul. Aşağıpınar, in eastern Thrace, displays very different material culture traditions than sites that belong to the Fikirtepe Horizon, and the lithic data show this very clearly (Gatsov et al. 2017). While the eastern Marmara assemblages, including Barcın Höyük described above, yielded microblade assemblages and pressure flaked bullet cores, the Thracian side of Turkey (with the exception of a few sites along the coast) have no evidence of pressure flaking (Özdoğan 2014). Likewise, sites like Barcin and other eastern Marmara sites have consistent access to obsidian mostly from Central Anatolia. In contrast, western Marmara lithic assemblages are characterized by Karanovo I-type blades, and obsidian is completely absent at sites like Aşağıpınar, although some coastal sites have yielded small quantities (Özdoğan 2014.42). Differing burial customs are another indication of this regional boundary. If we consider burials as reflective of societal beliefs then it is noteworthy that no burials have been uncovered from western Marmara sites, whereas Barcin and other sites in the eastern Marmara, including Ilıpınar, Fikirtepe, Pendik, and Yenikap1, have ample evidence for human inhumations within and near the settlements.

This final point on cultural boundaries can serve as a useful reminder of the need to maintain a critical, archaeological outlook on neolithisation processes. The new genetic paradigm that points to migration as a major mechanism in the expansion of farming (see above) leaves many archaeological questions unaddressed, questions about how and why people interacted and migrated, and about why they on occasion they also maintained cultural boundaries that prevented mobility and interaction. Both are aspects of the history of the spread of Neolithic ways of life from Anatolia to Europe.

The Barcın Höyük Excavations were conducted with permission from the Turkish Ministry of Culture and Tourism. Funding for the excavations and research was received from NWO (Netherlands Organization for Scientific Research), National Geographic, and the Netherlands Institute for the Near East.

\section{References}

Aksoy B., Özügül A. 2014. Kültür varlı̆gı alg1S1 ve tahribat Bursa Yenişehir örneği üzerinden bir değerlendirme. Uludă̆ Üniversitesi Fen-Edebiyat Fakültesi Sosyal Bilimler Dergisi 15(27): 297-306.

Akyol Ş. 2018. Neolitik dönemde Keçiçayır yerleşmesi. Unpublished MA thesis. Bilecik University. Bilecik.

Alpaslan Roodenberg S. 2009. Demographic data from the Byzantine graveyard of Barcin. In T. Vorderstrasse, J. Roodenberg (eds.), Archaeology of The Countryside in Medieval Anatolia. PIHANS 113. Leiden: 169-173.

Alpaslan Roodenberg S., Gerritsen F., and Özbal R. 2013. Neolithic burials from Barcın Höyük: the 2007-2012 excavation seasons. Anatolica 39: 93-111.
Arbuckle B. S., Kansa S. W., Kansa E., Orton D., Çakırlar C., Gourichon L., Atıcı L., Galik A., Marciniak A., Mulville J., and Buitenhuis H. 2014. Data sharing reveals complexity in the westward spread of domestic animals across Neolithic Turkey. PLoS ONE 9(6): e99845.

https://doi.org/10.1371/journal.pone.0099845

Balc1 H., Cappers R. T., Gerritsen F. A., and Özbal R. D. 2019. Barcin Höyük'te bitki seçimi: 2013-2015 y1lı arkeobotanik sonuçlarının değerlendirilmesi. Arkeometri Sonuçları Toplantısı 34: 333-352.

Baysal E. 2014. A preliminary typology for beads from the Neolithic and Chalcolithic levels of Barcin Höyük. Anatolia Antiqua. Revue internationale d'archéologie anatolienne 22: 1-10. 
Bigazzi G., Oddone M., and Yeğingil Z. 1995. A provenance study of obsidian artifacts from Ilipinar. In J. Roodenberg (ed.), The Ilipinar Excavations I. Five Seasons of Fieldwork in NW Anatolia, 1987-91. PIHANS 72. Leiden: 143-150.

Bigazzi G., Poupeau G., Yeğingil Z., and Bellot-Gurlet L. 1998. Provenance studies of obsidian artefacts in Anatolia using the fission-track dating method: an overview. In M. C. Cauvin (ed.), L'Obsidienne au Proche et Moyen Orient: Du Volcan - l'Outil. British Archaeological Reports IS 738. Archaeopress. Oxford: 69-89.

Bottema S., Woldring H. 1995. The prehistoric environment of the Lake Iznik Area; a palynological study. In J. Roodenberg (ed.), The Ilptnar Excavations I: Five Seasons of Fieldwork in NW Anatolia, 1987-91. PIHANS 72. Leiden: 8-16.

Bottema S., Woldring H., and Kayan I. 2001. The late quaternary vegetation history of Western Turkey. In J. Roodenberg, L. Thissen (eds.), The Ilpınar Excavations II. PIHANS 93. Leiden: 327-354.

Bursalı A., Özbal H., Özbal R., Simșek G., Yağci B., Yilmaz C., and Baysal E. 2017. Investigating the source of blue color in neolithic beads from Barcın Höyük, NW Turkey. In T. Pereira, X. Terradas, and N. Bicho (eds.), The Exploitation of Raw Materials in Prehistory: Sourcing, Processing and Distribution. Cambridge Scholars Publishing. Cambridge: 491-504.

Cappers R. T., Balc1 H. n.d. The 2014 botanical report. Unpublished Botanical Report Submitted to the Barcin Höyük Excavation Project, August 2015.

De Groot B., Thissen L., Özbal R., and Gerritsen F. 2018. Clay preparation and function of the first ceramics in north-west Anatolia: a case study from Neolithic Barcin Höyük. Journal of Archaeological Science: Reports 16: 542-552. https://doi.org/10.1016/j.jasrep.2017.06.028

Erdalkıran M. 2016. Barcın Höyük Neolitik dönem kemik kaşıkları. Türkiye Bilimler Akademisi Arkeoloji Dergisi 18: $25-36$.

Evershed R. P., and 21 co-authors. 2008. Earliest date for milk use in the Near East and Southeastern Europe linked to cattle herding. Nature 455: 528-531.

https://doi.org/10.1038/nature07180

French D. 1967. Prehistoric sites in Northwest Anatolia I. Iznik Area. Anatolian Studies 17: 49-101.

Galik A. 2013. Barcın Höyük zooarchaeology. on-line http://opencontext.org/projects/74749949-4FD4-4C3EC830-5AA75703E08E https://doi.org/10.6078/M78G8HM0
Gatsov I. 2003. The latest results from the technological and typological analysis of chipped stone assemblages from Ilıpınar, Pendik, Fikirtepe and Menteşe, NW Turkey. Documenta Praehistorica 30: 153-158. https://doi.org/10.4312/dp.30.9

Gatsov I., Nedelcheva P., Özbal R., and Gerritsen F. 2009. Prehistoric Barcın Höyük: 2007 excavations and chipped stone artifact analysis. In F. Drasovean (ed.), Ten Years After: The Neolithic of the Balkans as Uncovered by the Last Decade of Research. Timisoara: 35-48.

Gatsov I., Kay M., and Nedelcheva P. 2012. Lithic assemblages from the prehistoric settlement at Barcin Höyük, Northwestern Anatolia. New Results. Eurasian Prehistory 9: $129-137$.

Gatsov I., Nedelcheva P. 2016. Earliest lithic material from Keçiçayırı site, Central NW Anatolia and Barcın Höyük, NW Anatolia. In Ü. Yalçın (ed.), Anatolian Metal VII: Anatolien und seine Nachbarn vor 10.000 Jahren. Anatolia and neighbours 10.000 years ago. Bochum: 95-98.

Gatsov I., Nedelcheva P. in print. Lithic production and social transformations in Marmara region during 7-6th mill. BC. Eurasian Prehistory 15.

Gatsov I., Nedelcheva P., Kaczanowska M., and Kozłowski J. 2017. Lithic industries and their role in neolithisation models in Southeast Europe. In A. Reingruber, Z. Tsirtsoni, and P. Nedelcheva (eds.), Going West? The Dissemination of Neolithic Innovations Between the Bosporus and the Carpathians. Proceedings of the EAA Conference, Istanbul, 11 September 2014 (Themes in Contemporary Archaeology 3). Routledge. London \& New York: 57-71.

Gerritsen F., Özbal R., Thissen L., Özbal H., and Galik A. 2010. The late chalcolithic settlement of Barcin Höyük. Anatolica 36: 197-225.

Gerritsen F., Özbal R., and Thissen L. 2013a. Barcın Höyük. The beginnings of farming in the Marmara Region. In M. Özdoğan, N. Başgelen, and P. Kuniholm (eds.), The Neolithic in Turkey. New Excavations and New Research. Vol. 5. Northwestern Turkey and Istanbul. Arkeoloji ve Sanat Yayinlari. Istanbul: 93-112.

2013b. The earliest neolithic levels at Barcin Höyük, Northwestern Turkey. Anatolica 39: 53-92.

Groenhuijzen M., Kluiving S., Gerritsen F., and Künzel M. 2015. Geoarchaeological research at Barcın Höyük: implications for the neolithisation of northwest Anatolia. Quarternary International 359-360: 452-461. https://doi.org/10.1016/j.quaint.2014.11.014

Hofmanová Z., and 38 co-authors 2016. Early farmers from across Europe directly descended from Neolithic 
Aegeans. PNAS. Proceedings of the National Academy of Sciences of the Unites States of America 113(25): 68866891. https://doi.org/10.1073/pnas.1523951113

Karul N. 2017. Northwest Anatolia: a border or a bridge between Anatolia and the Balkans during the Early Neolithic Period? In A. Reingruber, Z. Tsirtsoni, and P. Nedelcheva (eds.), Going West? The Dissemination of Neolithic Innovations Between the Bosporus and the Carpathians. Proceedings of the EAA Conference, Istanbul, 11 September 2014 (Themes in Contemporary Archaeology 3). Routledge. London \& New York: 7-18.

2019. Early Farmers in Northwestern Anatolia in the seventh millennium BC. In A. Marciniak (ed.), Concluding the Neolithic. The Near East in the Second Half of the Seventh Millennium BC. Lockwood Press. Atlanta: 267-285.

Kılınç G. M., and 13 co-authors. 2017. Archaeogenomic analysis of the first steps of neolithization in Anatolia and the Aegean. Proceedings of the Royal Society B: Biological Sciences 284: 20172064.

https://doi.org/10.1098/rspb.2017.2064

Kılınç G. M., and 26 co-authors. 2017. The demographic development of the first farmers in Anatolia. Current Biology 26: 2659-2666.

https://doi.org/10.1016/j.cub.2016.07.057

Lazaridis I., and 5 co-authors. 2016. Genomic insights into the origin of farming in the Ancient Near East. Nature 536: 419-424. https://doi.org/10.1038/nature 19310

Mathieson I., and 39 co-authors. 2015. Genome-wide patterns of selection in 230 Ancient Eurasians. Nature 528 . 499-503. https://doi.org/10.1038/nature16152

Mellaart J. 1955. Some prehistoric sites in Northwestern Anatolia. Istanbuler Mitteilungen 6: 52-80.

Milić M. 2014. PXRF characterisation of obsidian from Central Anatolia, the Aegean and Central Europe.Journal of Archaeological Science 41: 285-296.

http://dx.doi.org/10.1016/j.jas.2013.08.002

Özbal H., Thissen L., Doğan T., Gerritsen F., Özbal R., and Türkekul-Bıyık A. 2014. Yenikapı, Aşağıpınar, Bademağac1 ve Barcın çömleklerinde organik kalıntı analizi. Arkeometri Sonucları Toplantısı 29: 83-90.

Özbal H., Türkekul-Bıyık A., Thissen L., Doğan T., Gerritsen F., and Özbal R. 2012. M.Ö. 7. binyılda Barcın Höyük'te süt tüketimi üzerine yeni araștırmalar. Arkeometri Sonucları Toplantısı 27: 15-32.

Özbal R., Gerritsen F. 2019. Barcın Höyük in interregional perspective: an initial assessment. In A. Marciniak (ed.),
Concluding the Neolithic. The Near East in the Second Half of the Seventh Millennium BC. Lockwood Press. Atlanta: 287-306.

Özbal R., Özbal H., Gerritsen F., Türkekul-Bıyık A., and Doğan T. 2017. New observations for the Late Chalcolithic settlement at Barcın Höyük. In C.. Maner, M. Horowitz, and A. Gilbert (eds.), Overturning Certainties in Near Eastern Archaeology. A Festschrift in Honour of K. Aslihan Yener. Culture and History of the Ancient Near East Vol. 90. Brill. Leiden: 503-520.

Özdoğan M. 1979. Fikirtepe. Unpublished PhD dissertation. Istanbul University. Istanbul.

1983. Pendik: a Neolithic Site of Fikirtepe Culture in the Marmara Region. In R. M. Böhmer, H. Hauptmann (eds.), Beiträge zur Altertumskunde Kleinasiens: Festschrift für Kurt Bittel. Philipp von Zabern. Wissenschaftliche Buchgesellschaft. Mainz: 401-11.

1999. Northwestern Turkey: Neolithic Cultures in between the Balkans and Anatolia. In M. Özdoğan, N. Basgelen (eds.), Neolithic in Turkey. The Cradle of Civilization. Ancient Anatolian civilizations series. Arkeoloji ve Sanat Yayınları. Istanbul: 203-224.

2013. Neolithic sites in the Marmara Region: Fikirtepe, Pendik, Yarımburgaz, Toptepe, Hoca Çeşme, and Aşağ1 Pınar. In M. Özdoğan, N. Başgelen, and P. Kuniholm (eds.), The Neolithic in Turkey. New Excavations and New Research. Vol. 5. Northwestern Turkey and Istanbul. Arkeoloji ve Sanat Yayinlari. Istanbul: 167-269.

2014. A new look at the introduction of the Neolithic way of life in Southeastern Europe: changing paradigms of the expansion of the Neolithic way of life. Documenta Praehistorica 41: 33-49.

https://doi.org/10.4312/dp.41.2

2019. Early farmers in Northwestern Turkey: what is new? In A. Marciniak (ed.), Concluding the Neolithic. The Near East in the Second Half of the Seventh Millennium BC. Lockwood Press. Atlanta: 307-327.

Roodenberg J. (ed.) 1995. The Ilipinar Excavations I. Five Seasons of Fieldwork in NW Anatolia, 1987-91. PIHANS 72. Leiden.

1999. Investigations at Menteşe Höyük in the Yenişehir Basin (1996-97). Anatolica 25: 21-36.

2009. Byzantine graveyards from Ilıpınar and Barcin in Northwest Anatolia. T. Vorderstrasse, J. Roodenberg (eds.), Archaeology of the Countryside in Medieval Anatolia. PIHANS 113. Leiden: 154-167. 
Roodenberg J., Alpaslan Roodenberg S. (eds.) 2008. Life and death in a prehistoric settlement in Northwest Anatolia. The Ilpinar Excavations, Volume III. With contributions on Haclartepe and Menteșe. PIHANS 110. Leiden.

Roodenberg J., Thissen L. (eds.) 2001. The Ilipinar Excavations II. PIHANS 93. Leiden.

Seeher J. 1987. Demircihüyük III.1. A: die Neolithische \& Chalkolithische keramik, B: die frühbronzezeitliche keramik der älteren Phasen. Phillip von Zabern. Mainz.
Thissen L., Özbal H., Türkekul-Bıyık A., Gerritsen F., and Özbal R. 2010. The land of milk? Approaching Dietary preferences of Late Neolithic communities in NW Anatolia. Leiden Journal of Pottery Studies 26: 157-172.

Würtenberger D. 2012. Archäozoologische analysen am fundmaterial des Barcın Höyüks im vergleich mit ausgewählten fundstellen des 7. und 6. Jt. v. Chr. in Nordwest- und Westanatolien. Unpublished MA thesis. University of Vienna. Vienna.

\section{back to contents}

